\title{
EPICUTICULAR WAX ON STOMATA OF DAMAGED SILVER FIR TREES (ABIES ALBA MILL.)
}

\author{
TOMISLAV BAČIĆ ${ }^{1}$, LJILJANA KRSTIN ${ }^{1}$, JADRANKA RoŠA ${ }^{2}$, ŽELJKO POPOVIĆ ${ }^{1}$ \\ ${ }^{1}$ Faculty of Philosophy, Department of Biology \\ J.J. Strossmayer University \\ L. Jägera 9, 31000 Osijek, Croatia \\ 2 Department of Ecology, Croatian Forests \\ Vukotinovićeva 1, 10000 Zagreb, Croatia
}

(Received: August 16, 2004. Accepted: February 11, 2005)

\begin{abstract}
Condition of epistomatal wax on the abaxial surface of the current and previous-year needles of damaged silver fir trees (Abies alba Mill.), both from the polluted Risnjak and "clean" Donja Dobra sites in Gorski Kotar region, both influenced by pollutants coming from Europe, during two years, three times a year, were examined with Scanning Electron Microscope. In the course of time the wax tubules on the epistomatal rims of stomata in polluted, but also in "clean" needles surface, become fused and agglomerated rapidly to various extents of morphologically different types of amorphous wax crusts, primarily compact and particulate ones. This process begins very early, especially in polluted Risnjak site, and may be interpreted as a possible result of air pollution. However, the recrystalization, or production of new tubules, also appears relatively quickly in mostly cases. Quantitative estimations indicate a very large total amount of amorphous wax crusts in the current-year needles, and a very high percentage of the same wax in previous-year needles. Amorphous wax crusts cover stomatal pores, as well as the rims, disturbing the normal gas exchange. Statistically there is a signicant tendency of increase in wax degradation in the needles of the polluted site in comparison with those of the unpolluted one, but there is an insignificant wax degradation among the needles of damaged trees within each site. These results confirmed most of the research done in our preliminary report.
\end{abstract}

KEY WORDS: Pinaceae, Abies alba Mill., abaxial leaf epidermis, stomata, epicuticular wax changes, fir decline, air pollution.

\section{INTRODUCTION}

Like in many European and American countries coniferous forests in Croatia are also declining (Huttunen 1976a, b; Bernadzki 1983; Schulze et al. 1989; Komlenović and Rastovski 1992; Tikvić et al. 1995; etc). this phenomenon in our country is most expressed in Gorski Kotar (Bačić and Popović 1998), the region between the continetal part and the Mediterranean area, which is strongly influenced by different pollutants coming from the Rijeka region, northern Italy and even from the north and middle part of Europe. In the last case it is a consequence of the wind directions. The opinion that air pollution is the primary cause of forest decline, especially those of silver fir trees, in Croatia was first emphasized by Durbešić and Kerovec (1990), although it was known that other factors, abiotic, biotic and anthropogenic can be implicated, too (Opalički 1972; Spaić 1972; Glavaš 1987; 1992a, b). There is also a hypothesis (Obminski 1977) attributing the decline of the fir to a change in its genetic structure.
This work is the continuation of our preliminary investigations of abaxial epicuticular wax surface condition on stomatal rims of silver fir needles in Risnjak (Bačić and Popović 1998). But, this one research includes two different localities, polluted and "clean" sites, exclusively on needles of damaged trees, two years of investigations and statistical analyses of the results. Taking into account the results of our other investigations, done in this area on silver fir trees needles, too (Bačić et al. 2003; Bačić et al. 2004), it is possible to attribute the needle dying to the acid rain as well as to pollution, respectively. So, this paper has the aim to contribute to wider knowledge on the condition of epicuticular wax on stomata of damaged trees as a consequence of pollution at both localities.

\section{MATERIAL AND METHODS}

Material was studied from two sites which differed in the level of pollution. The first, the Risnjak site, was a po- 
lluted site, whereas the second, the Donja Dobra site, was an "clean" one. Both are situated in Gorski Kotar, the region between the Mediterranean and continental part of Croatia. Both sites are described in our previous paper (Bačić et al. 2003), here we are giving only the most important data.

Risnjak is at $700 \mathrm{~m}$ altitude, on a dolomite base with a limestone surface of average $\mathrm{pH}$ 6.07, and Donja Dobra is at $570 \mathrm{~m}$ altitude, also on a dolomite base, but with silicate surface of average $\mathrm{pH}$ 4.15. Sulphur dioxide concentration varied on the first site from 32.2 to $47.5 \mu \mathrm{m} / \mathrm{m}^{3}$ and on the other one from 16.5 to $23.9 \mu \mathrm{m} / \mathrm{m}^{3}$. At the Risnjak site higher concentration in the soil are recorded for $\mathrm{Zn}, \mathrm{Mn}, \mathrm{Mo}$, $\mathrm{Mg}$ and $\mathrm{Ca}$, and particularly for $\mathrm{S}$ as well as for most of heavy metals $(\mathrm{Pb}, \mathrm{Ni}, \mathrm{Cd})$, and at the Donja Dobra site 10 elements, like $\mathrm{Al}, \mathrm{Na}, \mathrm{K}, \mathrm{Fe}, \mathrm{Ti}, \mathrm{V}, \mathrm{Cu}, \mathrm{Co}, \mathrm{Ba}, \mathrm{Cr}$, are detected at much greater amount. Besides this, Risnjak was slightly cooler corresponding its altitude.

Sampling data were done three times a year, in May, July and September, during 1999 and 2000. In each site, ten trees of different damage stage were chosen. These stages were also previously described (Roša 2001; Bačić et al. 2003). According to these data the silver fir trees in Risnjak were quite visibly damaged as a result of air pollution, probably of acid rain. Their defoliation, chlorosis and crown architecture were assessed. The estimated damage of the trees ranged from 20 to $85 \%(35 \%, 55 \%, 30 \%, 35 \%$, $85 \%, 75 \%, 45 \%, 45 \%, 20 \%, 45 \%)$. The silver fir trees at the Donja Dobra site looked almost completely healthy. The estimated damage ranged here from 5 to $10 \%(5 \%$, $5 \%, 10 \%, 10 \%, 5 \%, 5 \%, 5 \%, 10 \%, 10 \%, 10 \%)$. From each of ten trees, aproximately from their middle part and from south side, three needles of two age-classes, of current and of previous-year ones, were sampled for experimental observations. It should be state that in these sites there were no completely undamaged firs. In all 90 needles of the current-year and 90 of the previous-year needles were taken in 1999 and the same was done in 2000. A total of 360 needles were sampled.

Segments ca. $6 \mathrm{~mm}$ from the middle region, previously dried for at least 24 hours to prevent fungal contamination, were cut and fixed to stubs with the use of the double-sided adhesive tape and subsequently were sputter-coated with gold. The investigation was done by using Scanning Philips XL Electron Microscope with the energy-dispersive system EDAX DX4. The accelerating voltage was $12 \mathrm{kV}$, take-off angle of $25^{\circ}$ and the counting time 60-100 live seconds. The screening and photographs were done at the Scanning Electron Microscope Laboratory of the INA company in Zagreb.

In the assessment were directly included ten abaxial stomata per each current and a previous-year needle. Thirty stomata per tree, or 900 stomata on each site per year, were observed.

\section{Quantification of structural changes}

To quantify the wax change the relative amount of amorphous wax on the epistomatal rims was used as a criterion for the level of crystalline wax degradation. Five stages were recognised in the extents to which epistomatal rims of stomata were covered with amorphous wax crusts:

Stage 1 - wax tubules were preserved, no amorphous wax at all;
Stage $2-1-20 \%$ of wax tubules were fused and agglomerated into amorphous wax crusts;

Stage $3-21-50 \%$ of wax tubules were fused and agglomerated into amorphous wax crusts;

Stage $4-51-80 \%$ of wax tubules were fused and agglomerated into agglomerated wax crusts and

Stage $5-81-100 \%$ of wax tubules were fused and agglomerated, so that wax tubular structure was not visible and amorphous wax crusts were present everywhere.

\section{Statistical analysis}

Ten stomata per one of three current and three previousyear needles, both from ten trees in each site, during the period of May to September of the year 1999 and 2000, were assigned to one stage number of epistomatal crusts formation. The mean index per tree was calculated and treatment differences per sampling data were analysed with Student's t-test (Sokal and Rohlf 1981). By this test the difference was significant at $\mathrm{P}>0.05(*)$.

\section{RESULTS AND DISSCUSION}

\section{General observations}

Like in Pinus sylvestris, or in other coniferous species, guard cells of silver fir needles (Abies alba Mill.) are deeply sunken and overtopped by subsidiary cells forming an epistomatal rim, which are not as conspicous as those of pine needles (Bačić et al. 1992, 1994), but this is the only part of stomata always easily visible in surface view (Fig. 1a).

The abaxial surface is primarily covered with a thin continuous layer of amorphous wax, on top of which the crystalloids of the so-called structural wax arise. The crystalloids appear as simple tubules. Although the tubules are known to be tubular, their tips are nearly always occluded (Fig. 2d). Fully developed rodlets could already be found on very young needles on the epistomatal rims, inside stomatal pores and sparsely on some non-stomatal areas.

With time this structure of wax rodlets is alterated to various extent, mostly resulting in an amorphous and almost flat wax crust (Figs 1b, 2c, d). This process apparently has a different start and intensity depending on the needle region and side. Judging by the appearance of the wax crusts already seen on very young needles, it seems that wax crystalloids transformation begins very early, immediately after they emerge.

On the epistomatal rims, where gradual changes of wax tubules started to appear first, three principal stages of wax degradation could be observed:

a) fusion and agglomeration of tubules,

b) advanced stages of agglomeration and

c) crust formation.

Our screening showed that epistomatal wax crusts most often started to develop on one side of the rim and then spread gradually around the epistomatal pore, covering the whole rim (Figs 1b, 2c).

Judging from the photomicrographs at higher magnification, epistomatal rim wax crusts on silver fir needles were not identical: two different types could be distinguished; compact amorphous crusts (Figs 2c, 4h) and pariculate amorphous crusts without recrystallized or newly crystal- 

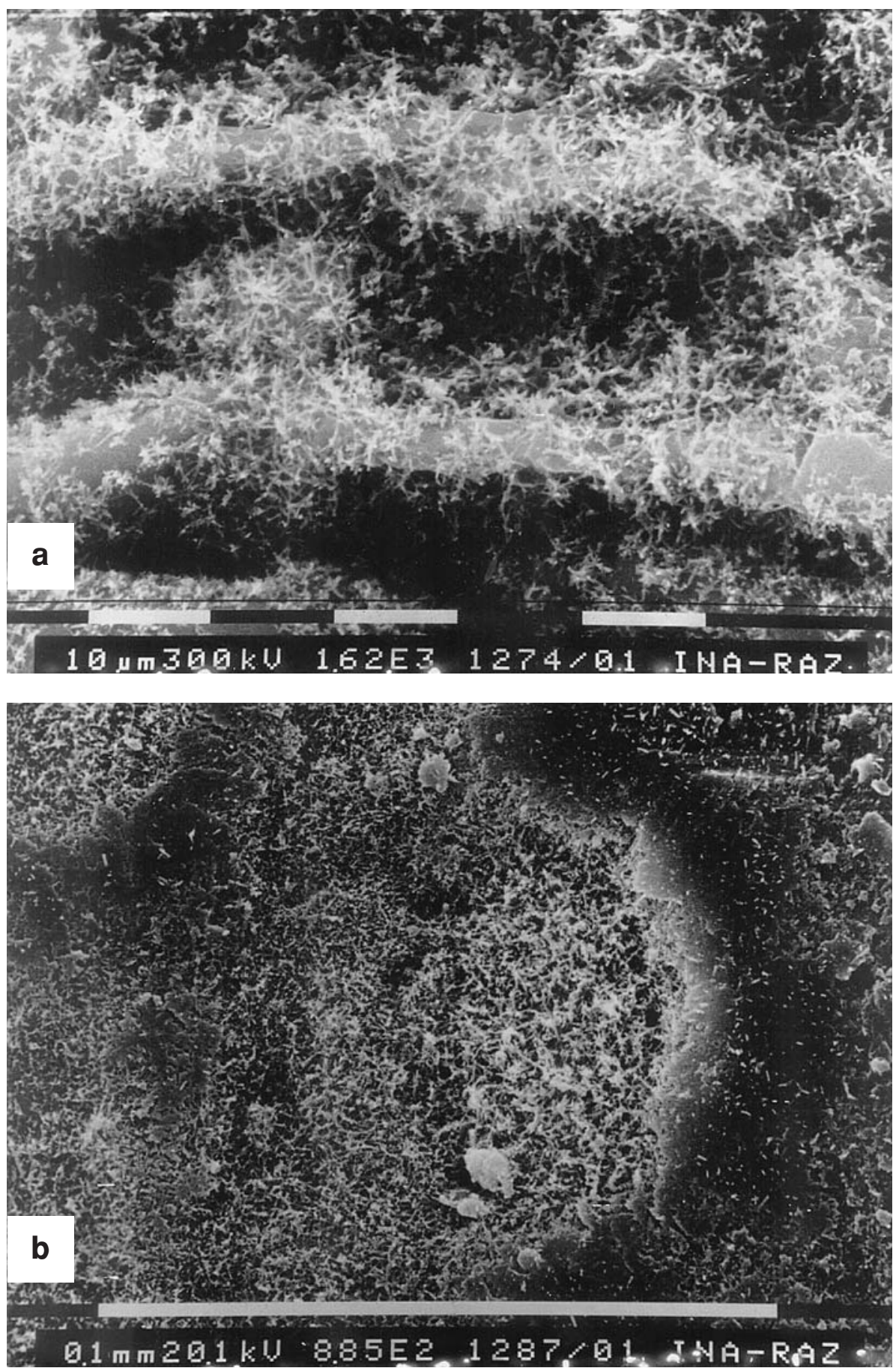

Fig. 1. Representative images of stomata showing crystal and amorphous wax stages on epistomatal rims: a) current-year needle from second tree in Risnjak site showing epistomatal rims exclusively with crystalline wax, stage 1 , amorphous wax absent and b) current-year needle from eighth tree in the Donja Dobra site showing stage 4, epistomatal rims covered with $21-50 \%$ of amorphous wax. lized rodlets and particulate crusts with recrystallized or newly crystallized rodlets (Fig. $4 \mathrm{~g}$ ).

Compact crusts occured in all the needles from all sampling dates, both in Risnjak and Donja Dobra, more frequently during July and in the current-year needles. Particulate crusts, which are probably a stage of crust degradation consisting either of coarsly flattened particles or of minor granulated ones, with or without recrystallized or newly crystallized wax, were also detected in all needles and all the sampling data. Interestingly, a lot of particulate amorphous wax crusts with recrystallized rodlets were mostly present in Donja Dobra, also in the course of July. A number of compact crusts seems to consist of aggregated outer-most parts of rodlets only, as the crystalloids structure underneath the crusts remained preserved. Also, some compact crusts, near the epistomatal pore, looked as if they were "melted" or partly dissolved. These kinds of wax crusts presumably represented a random phenomenon and occured primarily in Risnjak in the current-year needles (Fig. 4h).

We also found some stomata with fused tubules inside the stomatal antechambers forming a flat and solid wax plug or amorphous crust above the pore which was completely or partially occluding the stomata in most cases (Fig. 3e, f). These types of stomata were found in relatively low frequency on all sampling dates, especially in Donja Dobra in the previous-year needles during September. Completely open pores were found only on very young needles.

The emergence of rodlets could be detected on epistomatal areas in very young currrent-year needles which flushed in the first half of May in 1999 and 2000. On non- 

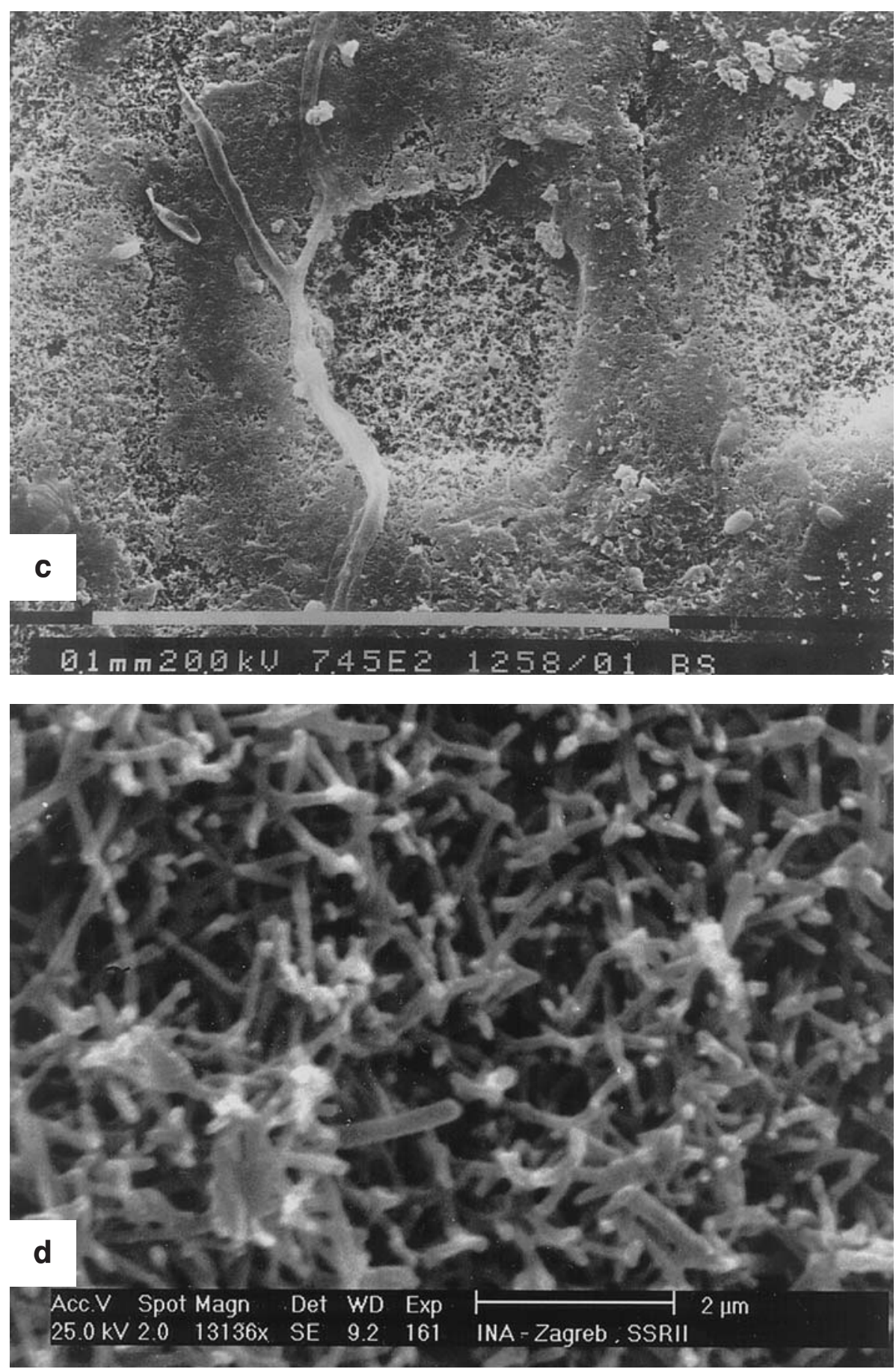

Fig. 2. Representative images of stomata showing amorphous wax stages on epistomatal rims and crystalline rodlets: c) previousyear needle from the first tree in the Risnjak site showing stage 5 , epistomatal rims covered with $81-100 \%$ of amorphous wax, and crystalline inside the stomatal antechambers, "melted" wax as well as mycelium of fungal hiphe and d) previous-year needle from the fifth tree in the Donja Dobra site with a stoma covered with simple tubular rodlets whose tips are occluded.

stomatal areas the rodlets started to emerge at the same time, but were sparcely. On the same very young needles the degradation of rodlets into amorphous wax crusts could already be observed.

Fungal mycelia, which probably belong to Hyphomycetes, were also detected, but sporadically on the needle surface of the current-year needles, generally with very rare occurence (Fig. 2c).

\section{Quantification of changes in wax morphology on epistomatal rims}

Stomata with amorphous wax crusts on the epistomatal rims of the abaxial surface were generally evident regadlles of sites, needle ages and sampling dates. However, frequency distribution of wax crystals in the shape of wax rodlets and amorphous wax in the shape of wax crusts on epistomatal rims on the needles collected during the period May-September of 1999 and 2000 show distinct differences between the sites, sampling dates as well as current and previous-year needles.

In accordance with our expectations in Risnjak frequency distribution of amorphous wax crusts prevailed in relation to Donja Dobra. In the first site, in the current and previousyear needles, during both years, particularly in July and September, the amorphous stage 5 was dominant (Figs 5, 6) The other stages were rare. During September of 2000 in the previous-year needles this stage was almost the only one (Figs 7, 8). On the contrary, in May, especially during 1999 in the site of Risnjak, but also in the site of Donja Dobra, there prevailed stages I, II, III and IV. But at the same time, it was noticed that in very young current-year needles the wax degradation was beginning very early and it had a tendency 

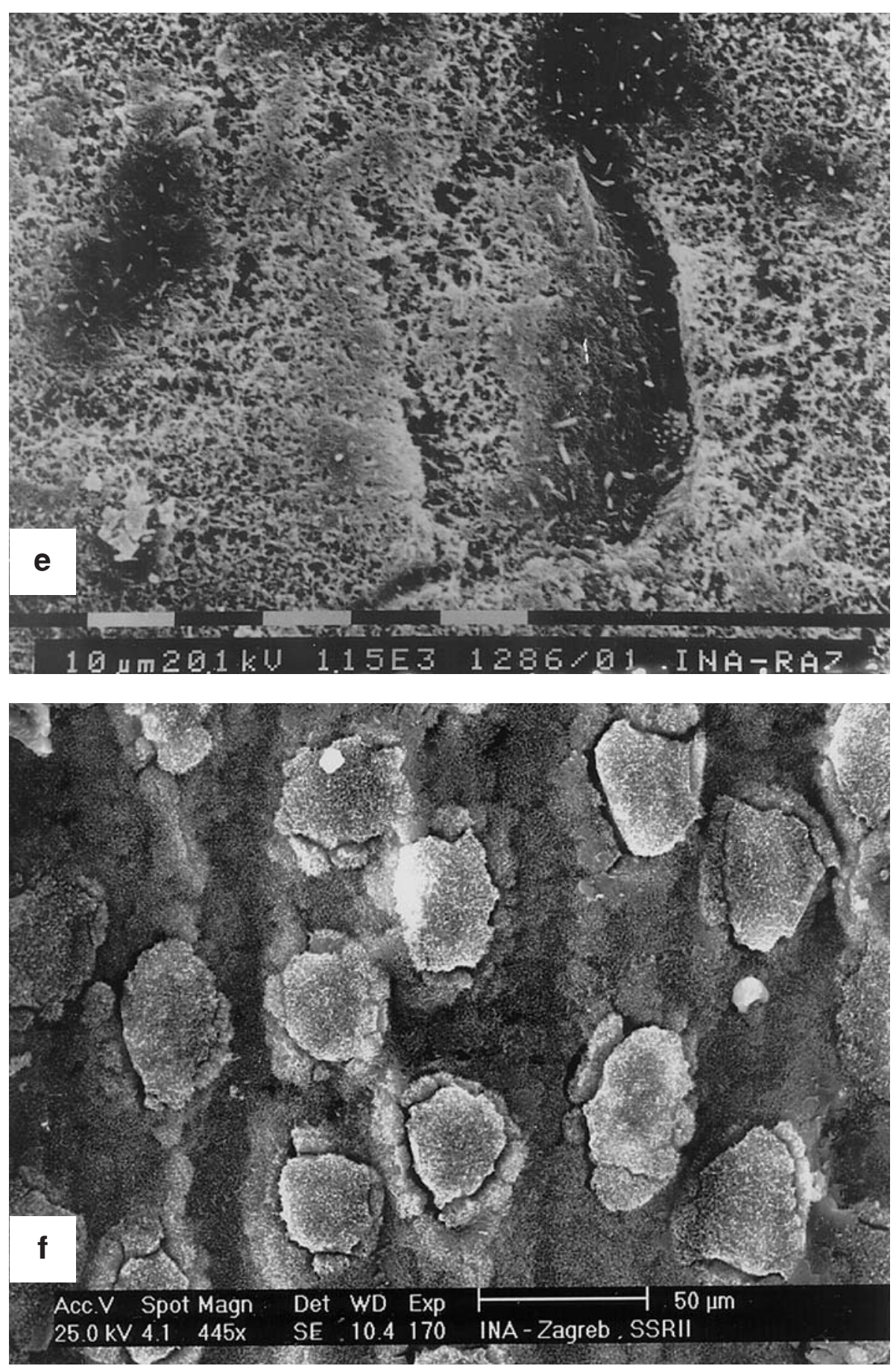

Fig. 3. Representative images of occluded stomata: e) previous-year needle from the second tree in the Risnjak site with a stomatal antechambers occluded with massive amorphous wax and f) current-year needle from the fourth tree in the Donja Dobra site with all stomatal antechambers occluded with massive wax.

to increase as was the case from early to late May. It should be stated that during this process of wax degradation compact and particulate wax crusts were arising, but in contrast to Risnjak, in Donja Dobra there was a trend of very early appearing of particulate wax crusts followed by recrystallyzed or new crystallized wax (Fig. 4g). Differences between both sites in the current and previous-year needles were evident and significant. They were particularly higher in the current-year needles in relation to the previous-year ones. However, no significant differences were found among the needles of different damaged fir trees in both sites, except during May 2000, when in the Risnjak site wax crusts were observed in the needles only of the most damaged fifth and sixth tree (75\% and $85 \%$ of damage).

According to many authors (Cape and Fowler 1981; Huttunen and Laine 1983; Riding and Percy 1985; Berg 1989;
Turunen and Huttunen 1990, 1991; Bačić et al. 1992, 1994) air pollution seems to increase the rate of wax tubules degradation, and therefore wax degradation may serve as an early biomarker of air pollution stress (Crosslay and Fowler 1986). Other authors, such as, Franich et al. (1977) and Thijsse and Baas (1990), sugessted that tubules, as labile structures, are naturally prone to degradation with time, so that both fusion and agglomeration into wax crusts may be treated as a normal phenomenon.

Nevertheless, the very early beginning of both fusion and agglomeration of wax tubules into wax amorphous crusts and the increasing percentage of amorphous wax stages in very young needles of the investigated firs, particularly in Risnjak during 2000, point to an accelerated process of wax degradation which is not only age-dependent but also influenced and accelerated by air pollution (Bačić and Popović 1998). 

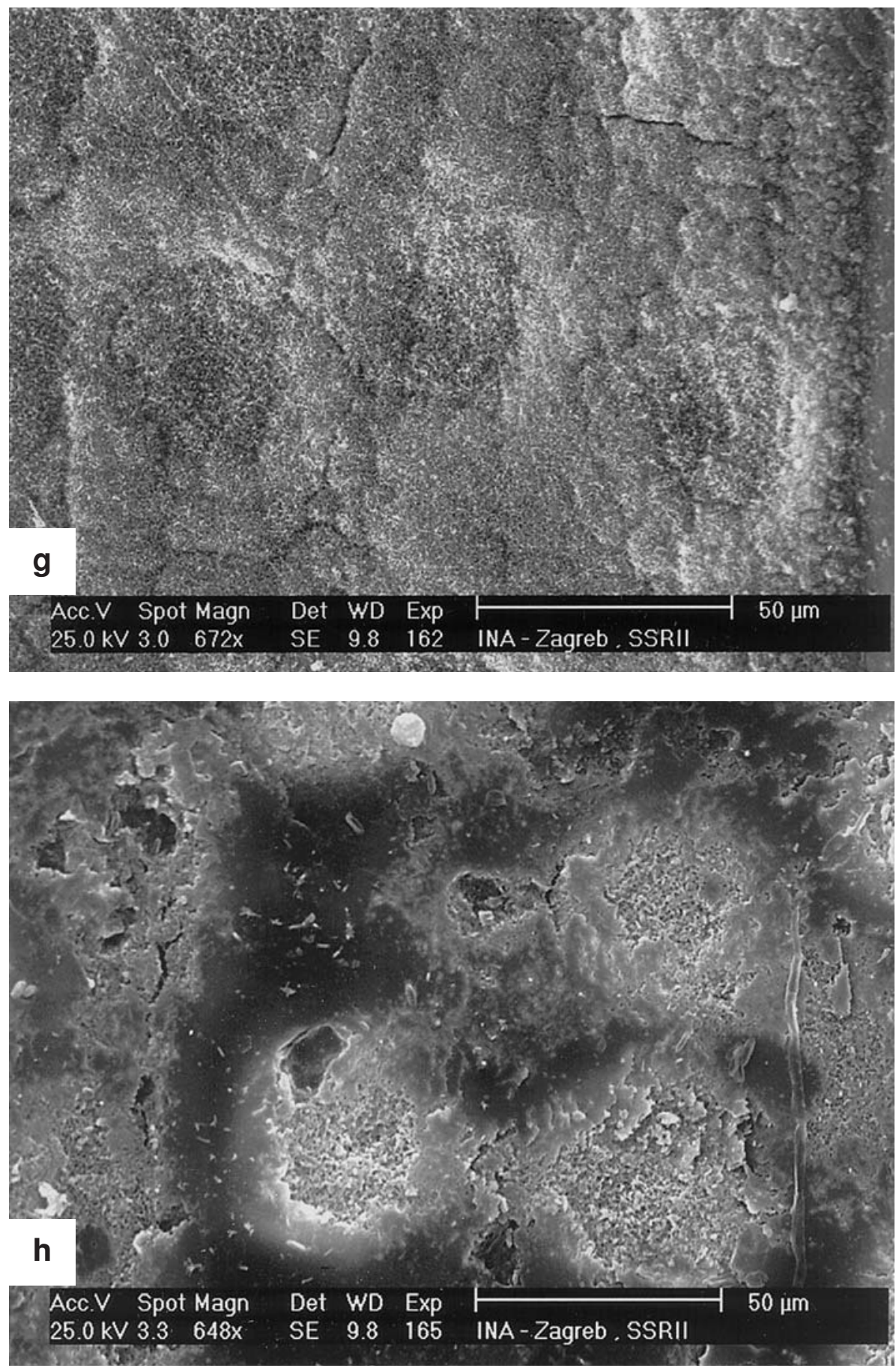

Fig. 4. Epistomatal rims covered with different types of amorphous wax crusts: g) current-year needle from the fourth tree in the Risnjak site with particulate wax crusts consisting of irregular but flat wax crusts covered with recrystallized or newly crystallized wax and h) previous-year needles from the sixth tree in the Risnjak site with compact and somewhat "melted" wax crusts mainly without wax rodlets.
Changes in wax tubules on fir needles take place not only on the epistomatal rims, but also, inside the stomatal pores. Such changes in the stomata either limit or obstruct gas exchange, and also impair protection against water stress. Occlusion of stomata by compact crusts (Figs 3e, f) may be one reason why the damaged fir needles fall off prematurely. The low epistomatal rims of the fir needle may enable environmental factors to impact the stomatal pore more easily (Bačić and Popović 1998).

Taking into account the data cited on the Risnjak site, refering to its level of pollution, the damage stages percentage of trees, the elemental composition and particularly the wind directions, the obtained results of very accelerated wax degradation into the wax crusts could be interpreted as the evidence that this habitat is much more polluted in comperison with the "clean" Donja Dobra site. These results confirm most of our preliminary investigations, too (Bačić and Popović 1998).

\section{ACKNOWELDEGEMENTS}

The authors would like to express their sincere gratitude to all persons who helped us, especially to Zvonimir Užarević for his help in statistical analysis, to engineers Mrs Renata Slavković and Mrs Zdenka Barbić of the INA Scanning Electron Laboratory for their useful assistance in making SEM microphotographs and to engineers Mr Ivan Malnar, Miljenko Gašparac, Željko Kauzlarić and Robert Bukovac as well as to Marijan Štimac of Risnjak for enabling us and assisting us in the collection of material. 


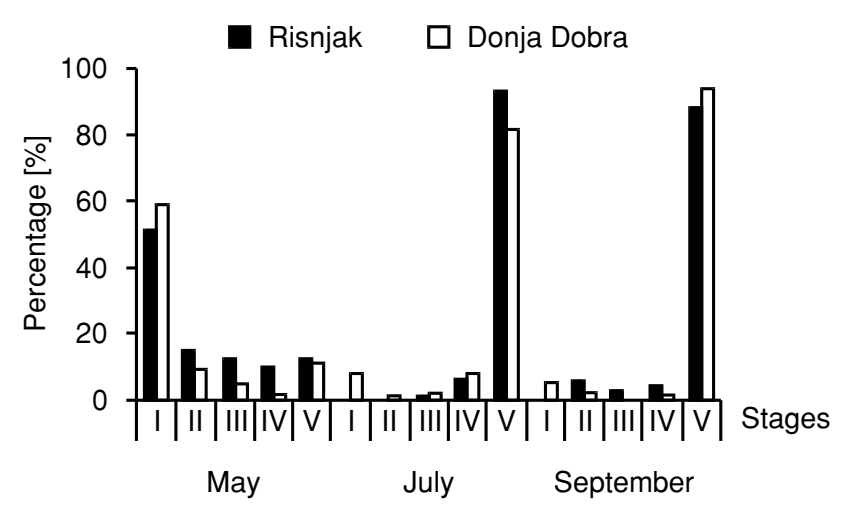

Fig. 5. Frequency distribution of structural (crystalline) and amorphous wax stage (crusts) at different sampling dates on epistomatal rims for current-year silver fir (Abies alba Mill.) needles during 1999.

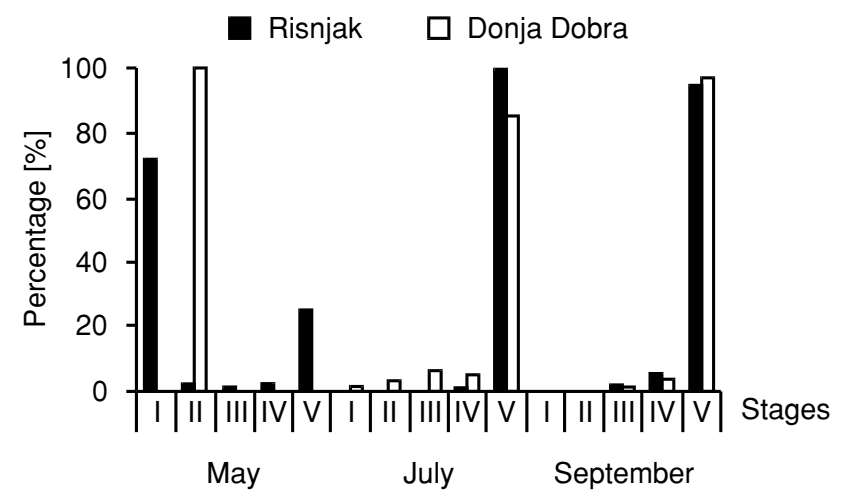

Fig. 6. Frequency distribution of structural (crystalline) and amorphous wax stage (crusts) at different sampling dates on epistomatal rims for previous-year silver fir (Abies alba Mill.) needles during 1999.

\section{LITERATURE CITED}

BAČIĆ T., BAAS P., VAN DER EERDEN L.J.M. 1992. Needle wax surface structure of Pinus sylvestris as affected by ammonia. Acta Bot. Neerland. 41: 176-181.

BAČIĆ T., VAN DER EERDEN L.J.M., BAAS P. 1994. Evidence for recrystallization of epicuticular wax on needles of Pinus sylvestris. Acta Bot. Neerland. 43: 271-273.

BAČIĆ T., POPOVIĆ Ž. 1998. Preliminary report on epicuticular wax surface condition on stomata of Abies alba Mill. needles from Risnjak National Park in Croatia. Acta Biol. Cracov., series Botanica 40: 25-31.

BAČIĆ T., GRGIĆ L.J., UŽAREVIĆ Z., ROŠA J., POPOVIĆ Ž. 2003. Chlorophylls and carotenoids in needles od damaged fir (Abies alba Mill.) from Risnjak National Park in Croatia. Acta Biol. Cracov., series Botanica 45: 93-98.

BAČIĆ T., LJUBEŠIĆ N., UŽAREVIĆ Z., GRGIĆ L.J., ROŠA J. 2004. Inveestigations of chloroplasts in needles of damaged silver fir trees (Abies alba Mill.) by transmission electron microsope (TEM). Acta Biol. Cracov., series Botanica 46: 145-149.

BERG V.S. 1989. Leaf cuticule as potential markers of air pollutant exposure in trees. In: Biologic markers of air pollution stress and in damage in forest. National Academy Press, Washington D.S.

BERNADZKI E. 1983. Zamieranie jodły w granicach naturalnego zasięgu. In: Jodła pospolita Abies alba Mill., 483-501. Instytut Dendrologii PAN w Kórniku k. Poznania, Warszawa-Poznań.

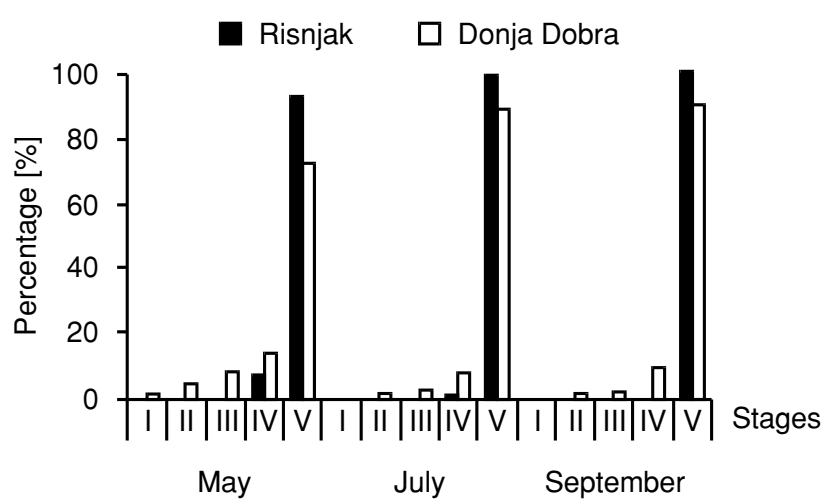

Fig. 7. Frequency distribution of structural (crystalline) and amorphous wax stage (crusts) at different sampling dates on epistomatal rims for current-year silver fir (Abies alba Mill.) needles during 2000.

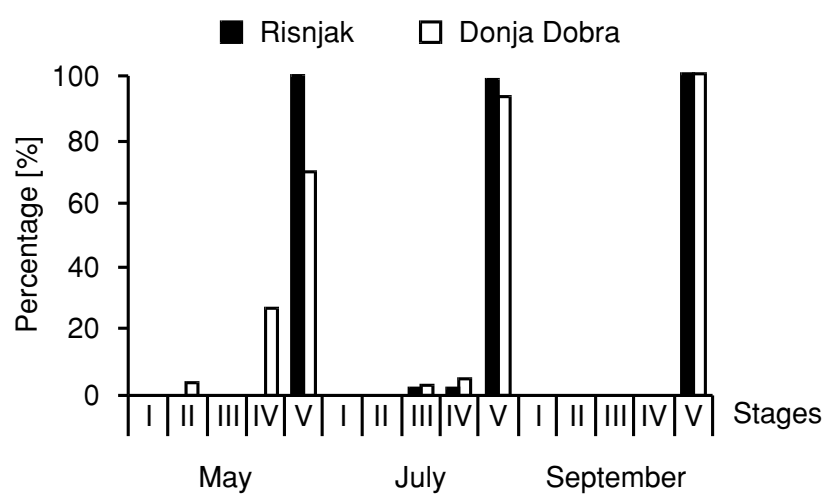

Fig. 8. Frequency distribution of structural (crystalline) and amorphous wax stage (crusts) at different sampling dates on epistomatal rims for previous-year silver fir (Abies alba Mill.) needles during 2000.

CAPE J.N., FOWLER D. 1981. Changes in epicuticular wax of Pinus sylvestris exposed to polluted air. Silve Fennici 15: 457$-458$.

CROSSLAY A., FOWLER D. 1986. The weathering of Scots pine epicuticular wax in polluted and clean air. N. Phytol. 103: 207-213.

DURBEŠIĆ P., KEROVEC M. 1990. Poziv za opstanak šuma. Ekološki glasnik 3-4: 31-32. (in Croatian)

FRANICH R.A., WELLS L.G., BARNET J.R. 1977. Variation within three age needle cuticule topography and stomatal structure in Pinus radiata. D. Don. Ann. Bot. 41: 621-626.

GLAVAŠ M. 1987. Nedelkrankhetien der Weistane in Kroatien. 5th IUFRO - Tannensymposium: 395-400.

GLAVAŠ M. 1992a. Diseases of the fir on the Velebit. 6th IUFRO - Tannensymposium: 213-218.

GLAVAŠ M. 1992b. Cytospora pinastri Fries. uzročnik osipanja iglica jele (Abies alba Mill.). Sumarski list 66: 57-62. (in Croatian)

HUTTUNEN S. 1976a. The influence of air pollution on the nothern forest vegetation. In: Kärelampi L. (ed.), Proceedings of the Kuopio meeting on plant damage caused by air pollution, 97-101, Kuopio 1976.

HUTTUNEN S. 1976b. Current research in Finland into the effect of air pollution. In: Kärelampi L. (ed.), Proceedings of the Kuopio meeting on plant damage caused by air pollution, 102109. Kuopio 1976.

HUTTUNEN S., LAINE K. 1983. Effects of air-borne pollutants on the surface wax structure of Pinus sylvestris. Ann. Bot. Fennici 20: 79-86. 
KOMLENOVIĆ N., RASTOVSKI P. 1992. Research of nutritional of silver fir (Abies alba Mill.) of different damage degree. 6th IUFRO - Tannensymposium: 183-190.

OBMINSKI Z. 1977. Ekologia lasu. Państwowe Wydawnictwo Naukowe, Warszawa. (in Polish)

OPALIČKI K. 1972. Spektar nekih štetnika jele u SR Hrvatskoj. Šumarski list 3-4: 131-145. (in Croatian)

RIDING R.T., PERCY K.L. 1985. Effects of $\mathrm{SO}_{2}$ and other air pollutants on the morphology of epicuticular waxes on needles of Pinus strobus and Pinus banksiana. N. Phytol. 99: 555-563.

ROŠA J. 2001. Praćenje šumskih ekosustava. Hrvatske šume, Zagreb.

SCHULZE E.D., LANGE O.L., OREN R. 1989. Forest decline and air pollution. A study of spruce (Picea alba) on acid soil. Ecological studies 77. Springer-Verlag. Berlin.

SOKAL R.R., ROHLF F.J. 1981. Biometry. W.H. Freeman, New York.
SPAIĆ J. 1972. Prilog poznavanju parazita jelinog igličara Argyresthia fundella T.R. Acta Entomol. Yugoslav. 8: 1-2. (in Croatian with English summary)

TIKVIĆ I., SELETKOVIĆ Z., ANIĆ I. 1995. Propadanje šuma kao pokazatelj promjene ekoloških uvjeta u atmosferi. Šumarski list 11-12: 361-371.

THIJSSE G. and BAAS P. 1990. "Natural" and $\mathrm{NH}_{3}$ induced variation in epicuticular needle wax morphology of Pseudotsuga menziensii (Mirb.) Franco. Trees 4: 111-119.

TURUNEN M., HUTTUNEN S. 1990. Structural changes in epicuticular waxes. J. Enironment. Qual. 19: 36-45.

TURUNEN M., HUTTUNEN S. 1991. Effect of simulated acid rain on the epicuticular wax of Scots pine needles under northerly conditions. Can. J. Bot. 69: 412-419. 